\title{
Further on the effects of ether anesthesia following one-trial discriminated avoidance learning ${ }^{1}$
}

MILTON D. SUBOSKI, JOSEPH LITNER AND MANUEL BLACK
QUEEN'S UNIVERSITY, KINGSTON, ONTARIO

Ether anesthesia administered either 100 or $3160 \mathrm{sec}$ after footshock significantly improved discriminated avoidance responding and reduced response latency only at the longer interval. Ether anesthesia as a highly aversive stimulus accounts for the results better than the hypothesis that ether disrupts memory consolidation.

Ether anesthesia following one-trial passive avoidance conditioning interferes with the acquisition of the avoidance response (Abt, Essman, \& Jarvik, 1961). The amount of the interference decreases as the interval between learning (footshock) and administration of ether increases (Alpern \& Kimble, 1967; Pearlman, 1966). These results are typically interpreted to mean that ether disrupts memory consolidation, thereby producing "retrograde amnesia" in the same way that electroconvulsive shock (ECS) is presumed to cause retrograde amnesia. However, recent work in our laboratory (Suboski, Spevack, \& Beaumaster, 1967) and elsewhere (Chorover \& Schiller, 1966; Pinel \& Cooper, 1966) strongly suggests that ECS delivered at relatively long postlearning intervals affects a conditioned emotional response (CER) rather than memory processes.

As has previously been pointed out (Beaumaster \& Suboski, 1967; Pfingst \& King, 1967), discriminated avoidance permits separation of performance and retention effects of experimental manipulations. We have reported investigations of ether following one-trial discriminated avoidance training (Black, Suboski, \& Freedman, 1967) with equivocal results. We report a similar experiment here, except that heated ether, two learning-ether intervals, and both passive and discriminated avoidance testing were used.

Method

Subjects. The Ss were 112 naive male Long-Evans rats, weighing approximately $250-300 \mathrm{~g}$ at the start of experimentation.

Apparatus. The apparatus has been previously described (Black, Suboski, \& Freedman, 1967). Essentially, it consists of a roughly triangular shaped lighted open field with two small dark chambers opening from two of the angles. The chambers are distinctive in color, shape and position. The floor of the open field is of plastic, those of the small chambers are electrifiable steel grids.

Procedure. The pretraining procedure was the same as that described by Black et al (1967). The Ss were given a series of four daily trials in which they were placed in the open field and allowed to enter one of the small chambers. Each free choice trial was followed by a forced choice trial in which the door to the chamber chosen on the previous day was closed. On the fifth day, again free choice, the grid floors of the small chambers were electrified with a $5 \mathrm{~mA}$ scrambled shock. In a large number of experiments using this technique, we have found that $80-90 \%$ of shocked rats choose the chamber in which they had not been shocked on a subsequent free choice test, whereas only about $33 \%$ of unshocked rats reverse their choice.

Fourteen Ss were randomly assigned to each of eight groups which formed the cells of a 2 by 2 by 2 factorial design. The factors were: treatment at $100 \mathrm{sec}$ or 3160 sec following shock, ether anesthesia or no ether anesthesia, and passive or discriminated avoidance testing. The Ss were removed from the apparatus $10 \mathrm{sec}$ after first encountering shock. They were then either treated $100 \mathrm{sec}$ after shock or returned to their home cage and treated $\overline{3} \mathbf{1} 60$ sec after shock. Treatment consisted of placing them for $100 \mathrm{sec}$ in one of two 2-quart plastic containers sitting in a water bath at $100^{\circ} \mathrm{F}$. Both containers had gauze pads covered by a wire screen at the bottom. In one container, the pads were kept soaked with diethyl ether. Testing was conducted $24 \mathrm{~h}$ later. Half of the Ss were given discriminated avoidance testing in which the doors to both small chambers were left open. The other half were given passive avoidance testing in which the door to the chamber not chosen on the previous day was closed, allowing $S$ to enter only the chamber where he had been shocked.

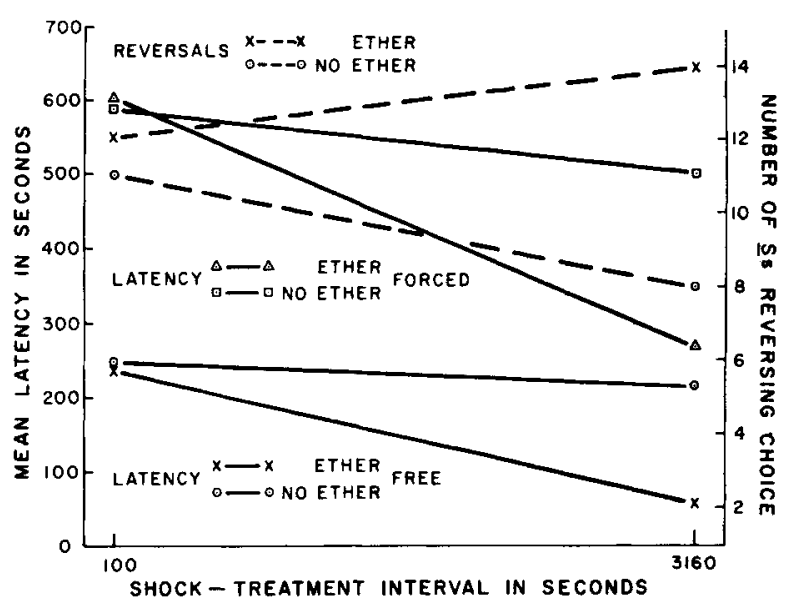

Fig. 1. Choice reversal and choice latency data for all groups. 


\section{Resulits}

Figure 1 presents both choice and latency data from the test trial. Examination of the choice data of the free choice tested groups reveals that Ss treated with ether discriminated better than unanesthetized Ss. The difference between the number of Ss reversing cholce in the Ether and No Ether groups, combined across shocktreatment interval, was significant by the normal approximation to the binomial $(z=2.35, p<.02)$. Fisher's exact test indicated a significant difference $(p<.01)$ at the $3160 \mathrm{sec}$ postshock interval, but not at the $100 \mathrm{sec}$ interval.

The latency data, with $1000 \mathrm{sec}$ used as the maximum score, indicate that forced choice testing produced considerably longer latencies of small chamber entrance than did free choice testing, and that the only effect of ether administration appeared to be a reduction in latency at the longer postshock interval. Analysis of variance of the latency data revealed significant effects of the type of testing $(F=23.25, \mathrm{df}=1 / 104, \mathrm{p}<.01)$ and the shock-treatment interval ( $F=6.50, \mathrm{df}=1 / 104, \mathrm{p}<.025)$. Both type of treatment $(F=2.44)$ and the interaction between shock-treatment interval and type of treatment $(F=2.51)$ gave large but nonsignificant $F$ values. No other $F$ ratio exceeded 1 . The failure of the interaction between the shock-treatment interval and the type of treatment to achieve significance is a little surprising from an examination of Fig. 1. Orthogonal comparisons between ether treated and nonether treated groups at each postshock interval revealed a significant effect of ether only at the $3160 \mathrm{sec}$ interval $(F=8.55, \mathrm{df}=1 / 104$, $p<.01$ ), with a small (.47) F value at the $100 \mathrm{sec}$ interval.

\section{Discussion}

The results of this experiment are not very consistent with the hypothesis that ether anesthesia interferes with temporally graded memory processes. However, the data are also not particularly consistent with previous (unpublished) data from the application of ECS. In several studies, we have found temporally decreasing latency gradients with free choice testing and the typical increasing gradient with passive avoidance testing following one-trial discriminated avoidance training and ECS. Here we find decreasing gradients with both free and forced choice testing. We also typically find poorer discrimination following ECS, but here ether apparently improved discrimination. The only explanation that comes close to fitting the data is that ether anesthesia served as a highly aversive stimulus.

\section{References}

ABT, J. P., ESSMAN, W. B., \& JARVIK, M. E. Ether-induced retrograde amnesia for one-trial conditioning in mice. Science, 1961, 133, 1477 1478.

ALPERN, H. P., \& KIMBLE, D. P. Retrograde amnesia effects of diethyl ether and bis (trifluoroethyl) ether. J. comp. physiol. Psychol., 1967, 63, 168-171.

BEAUMASTER, E., \& SUBOSKI, M. D. A one-trial discriminated avoidance conditioning technique. Paper read at Canadian Psychol. Assoc. meet., Ottawa, 1967.

BLACK, M., SUBOSKI, M. D., \& FREEDMAN, N. L. Effects of cortical spreading depression and ether following one-trial discriminated avoidance learning. Psychon. Sci., 1967, 9, 597-598.

CHOROVER, S. L., \& SCHILLER, P. H. Reexamination of prolonged retrograde amnesia in one-trial learning. J. comp. physiol. Psychol., $1966,61,3441$.

PEARLMAN, C. A., JR. Similar retrograde amnesia effects of ether and spreading cortical depression. J. comp. physiol. Psychol., 1966, 61, 306-308.

PFINGST, B. E., \& KING, R. A. A one-trial response-choice technique for the biological study of memory. Psychon. Sci., 1967, 8, 497498.

PINEL, J. P. J., \& COOPER, R. M. The relationships between incubation and ECS gradient effects. Psychon. Sci, 1966, 6, 125-126.

SUBOSKI, M. D., SPEVACK, A. A., \& BEAUMASTER, E. ECS effects in one-trial discriminated avoidance. Paper read at East. Psychol. Assoc. meet., Boston, 1967.

Note

1. We thank Carol Vanderleck and Frances Aldercotte for running some of the Ss. This research was supported by Grant No. 244 from the National Research Council of Canada and Grant No. 161 from the Ontario Mental Health Foundation. 